\title{
The Ethiopia-Eritrea Peace Talk and Normalization of Relations: Implication for Sub-Regional Security
}

\author{
Kidanu Atinafu Temesgen \\ Lecturer at Debre Markos University, Ethiopia
}

\begin{abstract}
This study attempts at shedding light on the security implication of the current Ethio-Eritrea new peace prospect and normalization of relations in the Horn of Africa. The study employed qualitative research approach. To realize the stated objective, the study largely focused at using secondary data sources, from which published and unpublished materials like books articles, reports, commentaries and agreements were reviewed and well consulted. To substantiate documented sources, the study used the analysis of experts and researchers presented on different media in the form of interview or focused discussion on the issue under investigation. The researcher herein argues that the ongoing diplomatic efforts to mend the decades of political impasse and hostility between Ethiopia and Eritrea can bring massive ramification in the process of ensuring peace in the Horn of Africa. In the first place, the recurring diplomatic rapprochement between the two foes can bring to an end the protracted acts of mutual destabilization and proxy war thereby address conflicts that have regional dimensions, as explained in terms of the intervention of Ethiopia on the side of transitional federal government $\mathrm{t}(\mathrm{TFG})$ of Somalia whereas Eritrea aligned with dissident groups fighting transitional federal government The other far reaching implication of the peace talk and normalization of Ethio-Eritrea relations is the opening of favorable grounds and platform for Eritrea-Somalia and Eritrea-Djibouti governments to reconcile antipathies and resume diplomatic ties. Equally important, prioritization of diplomatic discussion manifest the rethinking of how ineffective is the culture of militarism in the resolution of various irreconcilabilities, given the longstanding reliance of the two people on guns and violence. Thereafter, the new peace prospect pursued by these countries also widen opportunities for strengthening formative regional cooperation and integrations schemes in security, energy, tourism, transports, road and trade.
\end{abstract}

Keywords: Eritrea; Ethiopia; Horn of Africa; Normalization; Security.

DOI: $10.7176 / \mathrm{IAGS} / 79-01$

Publication date: January $31^{\text {st }} 2020$

\section{INTRODUCTION}

\subsection{Introductory Notes about the Horn of Africa}

The issue of defining the Horn of Africa is cumbersome due to the fact that different authors understood it on the basis of different determinants like historical, demographic, geographic, cultural and geopolitical considerations (Kassahun, 2013). Some used the Horn of Africa to refer Ethiopia, Djibouti, Eritrea and Somalia and consider them as the 'core Horns' as distinct from the 'Greater Horn of Africa' (Kassahun, 2013: 72) whereas other writers added all IGAD member countries as part and parcel of it. Recognizing all these understanding, in this piece of paper, the researcher used the Horn of Africa to refer member countries of IGAD with a special focus on the core Horns i.e. Ethiopia, Somalia, Djibouti, and Eritrea.

Exceptionally from other parts of Africa, the political environs of the Horn of Africa are known for being a volatile, war thorn, hostile and poor place due to numerous factors. It is heavily beaten by wars and conflicts of different sorts. According to Healy (2009), almost all the countries of region have faced intra- and inter-state conflicts of varying degrees and intensity over the past few decades (see also Kassahun, 2013). A good demonstration of the inter-state wars witnessed since the late 1950s includes "the Ethiopian-Somali wars (1964, 1977-78 war and the 2006-9 military intervention), the Kenyan-Somali war (1963), the Ugandan-Tanzanian war (1978-79) and the Ethiopian-Eritrean border war of 1998-2000" (Kidane, 2013:28) and the EritreaDjibouti border discord of 2008. Prompted by the dreadful conditions of the environment and porous border, destructive cross-border communal conflicts also recorded in the region (Kidane, 2013).

The volatile nature of the region attracts researchers and policy makers to undertake inquiries about its cause and possible solutions. Most importantly, a long and complex history, international intervention, state formation processes and struggles, political economy, identity conflicts and environmental change are found as interacting issues behind the turmoil (see Bereketeab, 2013).

Of the above listed inter-state wars, the Ethio-Eritrean war of 1998-2000 was found to be the largest and deadliest conventional war of the late twenty century. The war cost the lives of tens of thousands of soldiers, consumed huge amount of money, and displaced people from their ancestral lands and the unspeakable torture and humiliation of civilians (see Abink, 1998; Daniel and Paulos, 2011; Kidist, 2011).

Though governments of the two protagonists associated the cause of the war to border discord, most scholars linked the roots of the war to different factors and hence finding a single conventionally agreed cause is 
problematic. Some found the growing of divergences in their economic policies and relations including the introduction of Eritrean currency-nakfa-as the cause of the war (see Abbink, 1998; Tekeste and Tronvoll, 2000;Dima, 2006; Bereket, 2010Kidist, 2011) whereas Alemseged (2001), Berhane (2006) and Gerbu (2006) identified the ambition of Eritrean government to build a unique Eritrean identity and mental map through detaching the Eritrean highlanders from their brothers living south of the Mereb River as the driving scene for the war. Ruth Iyob (2000) also stated the asymmetric visions and hegemonic competitions leaders of the two countries want to have in the region as the leading factor to conflict while some other writers exhibited the unholy alliance, deep rooted mistrust, political and ideological differences of the two protagonists, TPLF and EPLF (see Trivelli, 1998; Medhane, 1999; Tekeste and Tronvoll, 2000; Healy and Plaut, 2007; Bereketeab, 2010). The other worth mentioning explanation is the one portrayed by Abbink (1998), Trivelli (1998)and Dima (2006) which associated the unfolding of the war to the lack of democracy and unaccountability of the governments in both countries whereas Leenco (2003) conceived the colonially induced superiority-inferiority complex between the two Tirgigna speaking people as the axis of divergence, given that the Eritrean highlanders considered themselves as unique, exceptional and civilized as compared with their Ethiopian counterparts.

The two years tragic fight, however, ended with the conclusion of the Algiers Agreement that established Eritrea Ethiopia Boundary Commission (EEBC) to settle the border dispute. The two parties agreed that the decision of the commission is binding thereby re-negotiations over the decision had been stymied. Accordingly, the commission passed its ruling on 2002, based on which the disputed flashpoint-Badme- was granted to Eritrea. The failure and stiff refusal of the Ethiopian government to accept the decision further muted the implementation of the decisions passed by EEBC, and hence restorations of the bilateral diplomatic ties remained farfetched for the last two decades.

In this vein, various literatures and research outcomes revealed that the conflicts witnessed in the Horn of Africa are closely intermingled and feed into each other by assuming sub-regional and regional dimensions (Kassahun, 2013). Concurrently, the Ethiopia-Eritrea war of the late twenty century and the un-curtailed postwar hostilities blamed for diluting the political stability of the region at large. As inferred by Bereketeab (2013), the war between Ethiopia and Eritrea goes beyond being sites of conflict within national borders, but it can be conflict actors in intra-state conflicts in neighbouring countries (See also Lyons, 2009; Mosley, 2014; Wuhibegezer, 2013). This is to mean that the unfolded tense relations and stalemate between Ethiopia and Eritrea following the conclusion of the war induced unpleasant ramifications for neighboring states.

However, after decades of hostility and impasse, the new peace prospect undergoing is assumed to curtail the discrepancy and enmity thereof. The appointment of Abiy Ahmed-a reformist as most called him- as Ethiopian new prime minster helped much for the prevailing rapprochement and decision to execute the Algiers Agreement and rulings of the EEBC. The newly appointed Ethiopia's head of government showed interests to implement decisions of the EEBC unconditionally thereby demanded to forge solidarity with Eritrea. His strong call to the Eritrean President for reconciliation also brought surprising result for the prevailing diplomatic progress between the two rivals. In this regard, this sudden breakthrough is assumed to have far reaching implication for the security of the Horn of Africa.

Thus, this article aimed at shedding light on the security implication of the current Ethio-Eritrea new peace prospect and normalization of relations in the Horn of Africa. The researcher herein argues that the ongoing diplomatic efforts to mend the long-lasting political impasse and hostility between Ethiopia and Eritrea can bring massive ramification in the process of ensuring peace in the Horn of Africa.

\subsection{Implications for Regional Security of Horn of Africa}

After years of stalemate and tension, Eritrea and Ethiopia are now officially at peace as the two leaders shake hands in fraternity. The meeting marked the determination of the two leaderships to end the senseless 'no-war, no-peace' situations. On July 9, 2018, the two leaderships passed a 'Joint Declaration of Peace and Friendship' ${ }^{1}$, which brings to an end the state of war between the two countries, and demarcation of the border based on the EEBC's rulings. Consensus was reached to forge cordial relations in multiplicity of fields like political, social, economic, cultural and security issues. They showed commitment to resume diplomatic ties, jointly pursue development projects and restored travel and communication lines between their people (Reuters, 2018). Subsequently, telephone lines opened for phone calls and commercial flights begun after decades of blockage. The two countries have also exchanged ambassadors and reopened old trade routes. All these developments subsequently lead us to believe that a new era of peace and friendship has been declared after years of frozen relations.

A more vigorous step towards ending the hostilities and normalize relations was done with the conclusion of a peace accord in the Saudi city of Jeddah on 17 September 2018 (Al Jazeera, 2018). The agreement contains

\footnotetext{
1 See the declaration from https://eri-platform.org/wp-content/uploads/2018/07/Eritrea-and-Ethiopia-A-Joint-Declaration-of-Peace-andFriendship.pdf
} 
seven articles dealing with the end of the hostility and opening of new era to harness "comprehensive cooperation in the political, security, defense, economic, trade, investment, cultural and social fields on the basis of complementarity and synergy" (see article 2 of the agreement). ${ }^{1}$

In views of different commentators, analysts, researchers, observers and leaders, the contribution of resumption of harmonious ties between these two countries not only benefit the two countries but the entire Horn of Africa. They underscored that the prevailing Ethio-Eritrean diplomatic rapprochement and decision to end the decades of stalemate as critical step to restore stability and sustain development in the impoverished Horn of Africa. Notably, the breaking of the stalemate could significantly address conflicts that have regional dimensions. This paper thus attempted at shedding light on how the Ethio-Eritrean peace talk and normalization eased the roads to bring stability in the war-ravaged Horn of Africa.

\subsubsection{Reduces Border Skirmishes and Adversaries}

The conclusion of the 1998-2000 Ethio-Eritrean war was followed by heightened deployment of defense forces and construction of battlements along the shared frontiers. As stated by Berouk (2008), the military deployment along the Ethio-Eritrea border reached alarming proportions in the aftermath of the failed meeting of the EEBC in September 2007 (see also Mosley, 2014).Wuhibegezer (2013) also pinpointed the escalated deployment of thousands of troops on both sides of the Ethio-Eritrean border with small playing field of distance apart. The International Crisis Group (2005) estimated the deployment of nearly 200,000 troops along the shared frontiers as of 2005. The military build-up reached alarming proportion until the prevailing rapprochement. As a result, the Ethio-Eritrean border areas remained intensively militarized which in turn manifested itself with tensions, frequent border skirmishes and exchange of gunfire. Though neither side appear eager to go to war, tensions and shooting of guns on the shared border continued to escalate, the cost of which was insecurity and threat to the wellbeing of the local communities living on adjacent areas in particular and to the region in general.

The unabated relentless espionage and forcible incursions commonly brought tourists and civilians under hostages as well. For instance, on March 2007, the Eritrean backed armed groups- Afar Revolutionary Democratic Unity Front (ARDUF) - snatched around five British tourists from Denakil Depression together with their Ethiopian drivers and interpreters (Berouk, 2008; Tewodros \& Halellujah, 2014). Another worthwhile event was the killing of five European tourists (two Germans, two Hungarians and an Austrian) during their visit to the volcanic Afar region of Ethiopia in January 2012(The Guardians, 2012). The gunmen also injured two individuals and kidnapped four people. Similarly, in April 2012, the late prime minister of Ethiopia-Melese Zenawi- accused Eritrea of kidnapping more than hundred individuals engaged at taking out gold from border areas (Tewodros \&Halellujah, 2014). Though the Eritrean administration discards the allegations altogether, officials from the Ethiopian side repeatedly indicted Eritrea for organizing the incident through training and arming the attackers. The abduction and killing consequently ignited tensions. In response to the incidence, the Ethiopian government noticed that it had assaulted three military battlements inside Eritrea used by rebels (Tewodros \&Halellujah, 2014).

Furthermore, Ethiopia also accused the government of Eritrea for infiltrating organized terrorists and mercenaries to destabilize and commit a terror attack in its territory, an allegation refuted by Eritrea leadership on the whole. In this vein, the official releases from the Ethiopian government on May 2016 disclosed that several Eritrean mercenaries were caught by Ethiopian security forces when conspiring to commit a terrorist attack around southern regional states (Sudan Tribune, 2016). The documents bearing out the identity of these mercenaries infiltrating to Ethiopia via Moyale in neighbouring Kenya was prepared by the Eritrean leadership (Sudan Tribune, 2016). The charge also continued until the recent incident to attack the Grand Ethiopian Renaissance Dam, where the armed groups participated in the action was reportedly from Eritrea (Mahmood and Meressa, 2018). Similar patterns emerged elsewhere in the country showing that the ruptured relations between the two protagonists endured destabilization in the region.

Whatsoever blames and subsequent denials, the political and military adversaries scarred the citizens of both countries, and have proved costly describing in terms of the lives lost, economic development foregone and endless instability. The thwarted post-Algiers relations not only pose immediate and urgent security threats and humanitarian crises to both countries, but also aggravated the internal problems of neighbouring countries since the two foes engaged in proxy fights.

Being informed of the adverse security impacts of the unmanaged border clashes and skirmishes, the two governments nowadays agreed to pullback the defense forces stationed along the disputed areas. The fortress and battlements built on both sides of the shared borders officially closed and the borders reopened for road transports and trade (Reporter, 2018).A speech made by the Ethiopian prime minister to the defense forces of the two countries stationed along Zalambessa and Bure fronts revealed that the mentality to hurt and see one another as enemy had come to an end and future effort shall be geared at helping the starved members of the respective

${ }^{1}$ Available at Addis Standard,( September 18, 2018) 'Full Text of the Ethio-Eritrea Agreement in Jeddah", https://addisstandard.com/fulltext-of-the-ethio-eritrea-agreement-signed-in-jeddah/. 
societies. Thereafter, tensions and alarming war likelihood over the shared borders ceased after the visit made by the Abiy Ahmed on Zalambessa and Bure battlements on the Ethiopian New Year (Reporter, 2018).

The opening of borders and the withdrawal of soldiers from disputed borders, pave the way for the free flow of people and goods between the neighbours. Most importantly, the reopening of Bure fronts gives-a region that saw some of the fiercest fighting- landlocked Ethiopia access to the sea (Al Jazeera,2018). The unlawful incursion and stifling of civilians, tourists and respective defense forces stationed along the shared EthiopiaEritrea border can be halted. The solidarity, closing of battlement and pullback of defense forces can potentially lessen the tensions and exchanges of gunfire and other adversary activities. The economic advantage is also there in the sense that huge amount of money expenditure to feed and sustain soldiers can be invested to other development projects.

\subsection{2. $\quad$ Reduces Mutual Destabilization and Proxy War}

The actors to the political instability of Africa in general and the Horn of Africa in particular involves both state actors (refers national governments and its bureaucratic organs) and non-state actors (like militias, rebel groups and armed bands) (Bereketeab, 2013). Especially, the spread of non-state actors in some countries of the Horn was found as the prime actors for festering conflict and instability. Though the driving scene behind the act of mutual intervention and destabilization are varied, states which are at the logger head pursued the strategy of providing safe heaven to certain armed groups and insurgents in their territory. Some intervene in the affairs of the other states as a result of its ethnic lineages with the rebel groups whereas some others backed insurgents in neighbouring countries to further national interests (Bereketeab, 2013).All in all, the practice of mutual destabilization and subversion remains the age-old policy action and peculiar characteristics of governments in the Horn of Africa (Healy, 2009; Kidanu and Endalcachew, 2015).

In this stare, Kassahun (2013) presented the Somalia and Sudan support of anti-Imperial and Derg regime forces like Eritrean insurgent groups, the Tigray People's Liberation Front, the Ethiopian Democratic Union (EDU) and the Oromo Liberation Front as worth mentioning (see also Healy, 2009). Ethiopia also took reciprocal measures through having extended hands to anti-Somalia government groups like Somali National Movement (SNM), Somali Salvation Democratic Front (SSDF) and Sudan People Liberation Movement-SPLM of Sudan (Abbink, 2003a; Kassahun, 2013). Through this practice, governments in the region plugged with the vicious cycle of mutual destabilization and subversion.

This policy and practice further persist with regard to the post-war Ethiopia-Eritrea relations. The unresolved border deadlocks led the two foes to actively engage at supporting each other's oppositions and armed groups (ICG, 2003; Bereketeab, 2013; Mosley, 2014). The relative intransigencies from the part of the government in Addis Ababa and Asmara to execute the ruling of EEBC or reopen negotiations on the decision of the commission escorted to the escalation of the act of subversion and destabilization. With the ambition of annihilating each other, the two governments engaged at supporting insurgents, guerilla fighters, oppositions, belligerents both strategically and logistically. In this connection, the Eritrean government provided sanctuary and assistance to anti-government movements operating both inside or outside of Ethiopia (Kassahun, 2013). Various armed and rebels' factions denouncing TPLF dominated EPRDF administrations, had offices in Eritrea over the last few years. Forces like Oromo Liberation Front (OLF), Ogaden National Liberation Front (ONLF), Ethiopian People's Patriotic Front-EPPF (Berouk, 2008; ICG, 2008; Lyons, 2009; Kassahun, 2013), Patriotic Ginbot 7 (Wuhibegezer, 2013), Tigray People's Democratic Movement (TPDM) (BBC, 2018) and Amhara Democratic Movement Force (ADMF) enjoyed safe heavens, training and military aid provided by Eritrean government. Almost all of these fronts supported by Eritrea sought to threaten and infiltrate to Ethiopia through the common borders, Sudan and, more importantly, Somalia (ICG 2008). As a counter response, Ethiopia also backed fragments of the Eritrean Democratic Alliance- EDA-(Berouk, 2008; Bereketeab, 2010) as well as the Eritrean Islamic Jihad/Islamic Salvation Movement, an Islamist group that was active in Eritrea with Sudanese support in the 1990s (ICG 2008). This action in turn perpetuated deeper political uncertainty, mistrust, animosity and irreconcilability between the two regimes.

The opening of the peace talks and normalization of relations, however, reduces the likelihood of fanning the policy of mutual intervention and subversion. Instead of backing the respective anti-government militants and oppositions, the administrations in both countries attempted to head peace talks with rebels and oppositions operating in the respective territories. Accordingly, the Eritrean backed fronts like; ONLF, Patriotic Ginbot 7, TPDM, OLF and ADMF decided to terminate their armed guerrilla operations and closed offices from Eritrea. Around 350 soldiers of ADMF, close to 1500 armed members of OLF (Reporter, 2018) and hundreds of forces of Patriotic Ginbot 7 returned to Ethiopia with the view to engage in peaceful struggle. The other Eritrean based armed opposition, TPDM also agreed to stop fierce struggle and hence close to 2,000 army of TPDM returned to Ethiopia following the signing of a peace agreement in August 2018 with the government in Addis Ababa (BBC, 2018). The Ethiopian government also ordered the Eritrean opposition parties to immediately cease all political activities against the Eritrean government on its soil (Plaut, 2018). The government makes clear that all opposition radio stations broadcasting from Ethiopia will be closed, and cancelling of slots on state-owned 
television (Plaut, 2018). These decisions can bring far reaching consequences to ensure the internal political stability and terminate the entrenched mistrusts and animosity between the two countries.

The hostility between Ethiopia and Eritrea in the aftermath of the war was not also confined to the culture of mutual subversion or destabilization, but it has also ignited proxy wars in the third countries (Lyons, 2009; Bereketeab, 2013; Mosley, 2014)). It is argued that the two contenders fought each other by helping rival groups in the war-torn neighbouring countries, notably in Somalia. Influenced by the motto of the "enemy of my enemy is my friend", the Eritrean administrations was repeatedly accused of backing Islamic Courts factions within the Union of Islamic Courts (UIC) while the government in Addis Ababa deeply aligned with the Transitional Federal Government (TFG) in its fight against Islamic Courts and affiliated militias (Lyons, 2009;ICG, 2010; Kidane, 2011; Kidist, 2011; Kassahun, 2013). The Somali's insecurity and instability therefore inevitable interfaced with the involvement of the two governments. The dissension between Ethiopia and Eritrea governments also inflicted the Sudan's internal turmoil (ICG, 2008). Hence, the post-war impasses between Ethiopia and Eritrea aggravated instability in the region.

The reconciliation of border incongruities and normalization of relations hence reduces the motivation to involve in proxy wars, given that the Ethio-Eritrean proxy fights in Somalia and to some extent in Sudan outsourced due to the unresolved border disputes. As hinted by ICG (2010), Eritrean engagement in proxy war with Ethiopia is intended to force Ethiopia to accept the EEBC decision. Therefore, the undergoing new peace prospects and breaking of the stalemate between the two contenders could significantly address regional conflicts of such sorts and sustain development in the Horn of Africa.

\subsubsection{Resort to Diplomacy Proficiency than Militarism}

As indicated above, the Horn of Africa typically attributed with instability and conflicts of all sorts. This political reality set states to stand against other states and communities against communities, thereby entrenched political turbulence and human misery. To come out of such awful conditions, conversion of civilian into military and para-military groups is the commonly observed policy action of governments in the region (Wasara, 2002), believing that militarism and use of force as viable means to secure political and other goals (Healy, 2009). This conduct substantially debarred states ability to pursue rational policies that call for social solidity and regional harmony. In this regard, Wasara (2002) concretely pinpointed out that the resort to militarism-emphasis addedand states inability to conversation with each other and with internal insurgents' endured violence and militarization of civilians.

On similar continuum, the post-war Ethiopia-Eritrea frozen relations was also exemplified with the ethos of militarism and militarization programs. Most importantly, the government in Asmara heavily engaged at training new military forces and remobilization of demobilized fighters and National Military Service conscripts (ICG, 2005; Healy, 2007), setting it as one of the militarized nations in Africa (ICG, 2010). The militarized policy of Eritrea forced the government in Addis Ababa to be suspicious and less cooperative to deal with those unsolved issues on the table. Instead, the government deeply involved at building strong combating forces so far to counteract the threat coming from Eritrea. The two foes thence continued to re-arm through buying aircraft, armoured vehicles and artillery from Eastern European countries (Plaut, 2005/2006) and huge resources exhausted for training soldiers and deploying force along the shared coastlines. Hence, a more militaristic, aggressive and violent policies was extensively employed, and the use of conventional diplomacy as preferred custom tools to deal with each other's divergences was shadowed over the last decades.

The resort to military adventurism and proxy engagement, however, criticized by different researchers, experts, analysts and even leaders. According to Kidanu and Endalcachew (2015) normalization of relations seems unrealistic in the absence of replacing the ethos of militarism with the new political and diplomatic proficiency. The historic relations between the two people rightly revealed that recourse to arms and militarism has not solved any of the outstanding problems (Bahru, 2006).

Being informed of this fact, the new Ethiopian Prime Minister, Abiy Ahmed, instigated the importance of sobering discussion, negotiations, diplomacy to deal with rebel groups and also with neighboring countries, notably with Eritrea. This approach can change the age-old culture and ethos of militarism and uses of violence the two people exhaustively rely since the dissolution of 1952 Ethio-Eritrean act of federation. Concomitantly, the resort to discussion and diplomatic proficiency can be taken as the major milestone to silence the guns and gun cultures in the regions, given the high motivation to use peaceful conflict resolution mechanisms in place.

\subsubsection{Restoration of Eritrea- Somalia Relations}

A strong perspective advanced by researchers showing interests in the political-economy of the Horn of Africa is the assertion that the post-war Ethio-Eritrea hostile relations worsened the security of Horn of Africa. Particularly, the consequence of the tense diplomatic ties between the two nations was evident in the failed republic of Somalia. According to Sally Healy (2009), the war between Ethiopia and Eritrea aggravated conflict within Somalia in the form of proxy war. Though the direct and deadliest war between Ethiopia and Eritrea was rare in the aftermath of the Algiers Agreement, it is strongly evidenced that the two countries fought each other in the third country-Somalia-through pouring logistics and other supports. While Ethiopia backed the 
Transitional Federal Government (TFG) of Somalia in its fight against Islamist and terrorist groups, the Eritrean government was repeatedly blamed for supporting the Somali Islamist groups and other anti-Ethiopian forces that sprung inside Somalia (Berouk, 2008; Kidane, 2011; Kidist, 2011; Kassahun, 2013). The leaders of the disbanded UIC and other Somali politicians who are allegedly given sanctuary by Eritrea formed the Alliance for the Re-Liberation of Somalia (ARS) in Asmara in 2007 (ICG, 2008; Kassahun, 2013). The most wanted individual by the UN Security Council as terrorist, Sheikh Hassan Dahir Aweys (Somalia national), was also sheltered and openly lived in Asmara (Daniel and Paulos, 2011).As a result of Eritrea's alleged support of Somalia's extremist rebel group like Union of Islamic court-UIC-and its outgrowth al-Shabab, the relations between Eritrea and Somalia heavily deteriorated and suspended diplomatic ties for the last few years.

As per the argument underscored by Berouk (2008), the settlement of the crises of Somalia is quite unobservable unless the Ethio-Eritrean conflict and hostility is resolved. On the face of it, the prevailing rapprochement and new peace prospects undergoing between the two antagonists opened up opportunities to restore diplomatic harmony between Eritrea and republic of Somalia. Following Eritrea's rapprochement with Ethiopia, new political development is emerging in cementing harmony between Eritrea and Somalia. The decision to mend the bilateral diplomatic relations made during a summit in Asmara, Eritrea, where Somalia President Mohamed Abdullahi Farmajo began a historic three-day visit on July 28, 2018 (Reuters, 2018).

The meeting was ended with the mutual agreement to forge intimate economic, political, social, cultural as well as defense and security cooperation (EBC,2018). Consensus was reached to resume diplomatic relations, promote bilateral trade exchange, investment and strengthen educational and cultural exchanges. The two governments showed an interest to work in unison to foster regional peace, stability and economic integration (African Review, 2018). The actual cooperation seems started when Somali president call for the removal all economic sanctions and embargo imposed on Eritrea due to the alleged support for the al-Shabab armed group in Somalia (Al Jazeera, 2018). ${ }^{1}$ His notice also geared towards revitalizing economic integration of the Horn of Africa.

\subsubsection{Resumption of Eritrea-Djibouti Relations}

The Ethiopia-Eritrea resentment and thwarted relations induced mixed outcomes on the political economy of a tiny Djibouti. On the one hand, the political and economic power of Djibouti reinforced as Ethiopia became utterly rely on it for port services (Berouk, 2008: Kassahun, 2013). From this transaction, substantial economic benefits go to Djibouti whereas Eritrea was forced to lose millions of dollars from its yearly revenue (Berouk, 2008: Kassahun, 2013). Ostensibly, resentment between Djibouti-Eritrea intensified when the former allowed Ethiopia to use its port for importing military equipment and other items from outside world. The resentment in a while ended with Eritrean support of remnants of Front for the Restoration of Unity and Democracy-FRUDagainst the Djiboutian regime (Kassahun, 2013). Hence, the cold war between Ethiopia and Eritrea also spilled over into neighboring Djibouti.

After long lasting tension and frozen relations, on 10 June 2008 fighting erupted between Djibouti and Eritrea over the control of Dumeira Mountain and Island, an area claimed by both countries (Berouk, 2008). The border skirmishes further inflicted enmity and fears of conflict that could potentially engulf the entire Horn of Africa. The decision of Abiy Ahmed to accept the Algiers Agreement however set favorable grounds in the reconciliation of Djibouti-Eritrea irreconcilability and restoration of diplomatic relations. In support of this idea, an exclusive interview made by Yacob Arsanoon the Ethiopian News Agency (2018) endorsed that the decision of the Ethiopian government to accept the EEBC decisions unconditionally and the desire to normalize relations with Eritrea can 'strengthen good relationship not only between Ethiopia and Eritrea but will also set a good example for the internal conflict in South Sudan; the misunderstanding between Republic of Sudan and South Sudan and also here in Africa'.

Months after Ethiopia notified its acceptance of the Algiers Agreement and consent to reconcile hostility with Eritrea; attempt had been made to mend the Djibouti- Eritrean discrepancies that beset the region into tensions and poor solidarity. The move was begun when Djibouti delegate-Mohamed Siad Douale-to the United Nations embarked that Djibouti demands the reconciliation of its incongruity with Eritrea. He said that:

'there is no escaping the fact that the international boundary remains disputed, Eritrea

continues to occupy Djiboutian territory, prisoners of war remain unaccounted for, threat of

force continue to emanate from the Eritrean side, and the risk of violent confrontation remains high' (VoA,2018).

He further urged Eritrea to resolve the border dispute peacefully with Djibouti in accordance with international norms and treaties. The allegation subsequently refuted by Eritrean counterpart, Nebil Said, stated that Eritrea

${ }^{1}$ The UN Security Council passed several sanctions and embargos on Eritrea as a result of its alleged funding and arming of al-Shabab militants in the failed Somalia and gross violation of human rights. The sanction include arms embargo, asset freeze, and travel ban. The asset freezes and travel ban further affected individuals and businesses as well as the Eritrean leadership role in global politics. Recently, the sanction was lifted after Eritrea's leadership shows commitment to resolve disputes with its neighbor and resume diplomatic relations with Ethiopia, Somalia, and Djibouti and to some extent with Sudan. 
had released all Djiboutian prisoners of war in 2016 and had never occupied Djiboutian territory (VoA, 2018). Underscoring the importance of the regional solidarity, the new administration of Ethiopia enthusiastically committed itself to mediate Djibouti-Eritrea mistrust and animosity. Concomitantly, headed by the foreign minister of Ethiopia, Eritrea and Somalia undertook a diplomatic visit to Djibouti that ended with the mutual understandings to normalize and restore bilateral relations (Reporter, 2018). Though further diplomatic efforts required in reconciling border claims and other intransigencies like the return of prisoners, the high-level diplomacy conducted by foreign ministers marked the end of longstanding tensions between Eritrea and Djibouti.

In the aftermath of the ministerial meeting of the three countries, high level summit diplomacy was conducted with the participation of the respective presidents of the two states, President Isaias Afwerki and Ismaill Omar Guelleh respectively, in Saudi Arabia (BBC News, 2018). The negotiated peace agreement between the two presidents brings to an end a decade-long conflict between the two countries (African News, 2018). In this vein, the resumption of Eritrea's relationship with Djibouti comes after Ethiopia and Eritrea bring to an end decade of impasses. And the sweeping reforms undertook by Ethiopia's new Prime Minister is widely credited for pursing Djibouti-Eritrea rapprochement and resumption of diplomatic thaws among neighboring countries.

Different political and conflict analysts found the peace talk and normalization of Djibouti-Eritrea relations as bedrock to enhance durable peace to the Horn of Africa. Acknowledging its detrimental effects, Omar Mahmood (a researcher at the Institute for Security Studies-ISS), argued that the reconciliations of border disagreement between Djibouti and Eritrea can "paves the way for not just the resumption of Eritrea's relationship with Djibouti, but its wider integration into the Horn of Africa" (Al Jazeera,2018). The agreement ushered a new dawn in relations among nations in the conflict-prone Horn of Africa.

\subsubsection{Facilitates Regional Integrations and Effectuation of IGAD}

As mentioned above, the well defining political features of the Horn of Africa is war and conflict. Almost all states experienced interstate and intrastate wars with varying degree and intensity. These turmoil and uncertainty further disrupted the establishment of formative regional integration and cooperation thereof. Among the other, the stalemate and unresolved border deadlock between Ethiopia and Eritrea found as the major security threats hampering the development and regional integrations schemes of the region (Berouk, 2012).

After years of impasses, Ethiopia and Eritrea are now at peace. The ongoing peace talk and normalization of relations between these two countries in this regard can be taken as significantly a necessary step to pursue further economic cooperation and integration. It can potentially change the landscape of politics in the Horn of Africa. An interview conducted with an Ethiopian historian, Professor Tesema Ta'a, in the Ethiopian News Agency denotes that the newly flourishing normalization between the two nations can open up opportunities to undertake economic integration in energy, trade, infrastructure, commercial and tourism (Ethiopian News Agency, 2018). Similarly, appreciating the undergoing peace deal, the European Union representative of the Horn of Africa-Alex Rondos- maintained that a new wind of hope is blowing across Africa and the prospect for real regional economic integrations created so far (Reuters, 2018), despite Mosley (2014) cautioned not to overstate the prospect of economic reintegration once relations between Eritrea and Ethiopia eventually improve.

Despite its incongruity with Eritrea, the Ethiopian government exhausted significant resources to facilitate regional integration in the Horn of Africa (Mosley, 2014). In this vein, the rehabilitation of Ethio-Djibouti rail link, the construction of roads and opening of road transport service, export of electric power and the agreements to jointly develop ports with its neighboring can be taken as a worth mentioning moment. Form all these intercourses; member countries of the Horn of Africa benefited much speaking in socio-economic and political terms. Particularly, Ethiopia is able to register a fast-economic growth over the past few years. To the contrary, Eritrea encountered significant negative economic impacts, given its tense relations with neighbouring countries, banning of the unfettered access of Ethiopian market and Ethiopia's shifts to Djibouti for port service than Eritrea

However, the experience after the restorations of Ethio-Eritrean diplomatic relations shows the intensified transactions in trade, transports, communications and people to people contacts. The easing of tensions resulted for the resumption of telecom service, airlines flights and reopening of embassies in the respective capital cities. Mutual understanding was also reached to rebuild infrastructural routes in and out of Eritrean ports. Huge influx of goods and commodities in and out of the two nations observed. The reopening of borders, air links, communication services, embassies, trade and infrastructural development can spur economic growth and economic interdependence, all of which might further lead to relatively stable environment and better cooperation among member countries of the region.

On September 5, 2015, a sort of tripartite agreement also initiated at the summit meeting held with the participation of leaders of Somalia, Eritrea and Ethiopia in the capital of Eritrea, Asmara. Agreement was reached to work in collaboration on regional peace and joint economic cooperation (Life and Peace Institute, 2018), which can be taken as a positive step in harnessing further integration projects.

Part of the contribution of the current diplomatic efforts to reconcile inter-state disputes might be the development of trust and confidence. It can help to mend the entrenched feeling of antipathy and mistrusts. The 
writing from Deutsch (1970 cited in Urgessa, 2014) reveals that the realization of successful cooperation and regional integrations requires the development of trust and confidence; in the sense of political harmony, spirit of compromise and cohesion; and the degree of mutual understanding and rapport, between and among member states. So the ongoing joint high level diplomacy to help mend the Ethiopia-Eritrea, Djibouti-Eritrea and EritreaSomalia relations could possibly foster political harmony, trust and sprit of cohesion especially in winning regional cooperation and development.

The other potential opportunity of the prevailing peace prospect between Ethiopia, Eritrea, Djibouti and Somalia is the effectuation of IGAD's credibility, relevance and its effectiveness in building stability in the sub region (Allafrican.com, 2018). Among the different agendas of IGAD, as a sub-regional organization of the Horn of Africa is the inducement of security, development and integration. It was primed to tackle security threats and development challenges. Despite its assumed role to reconcile the Sudanese internal strife and peacemaking efforts in Somalia (see Healy, 2009; Tewodros \&Halellujah,2014), IGAD's role to bring peace and contain conflict in the region remains implausible, noting its incapacitated ability to mend the Ethiopia-Eritrea and Djibouti-Eritrea border disputes Among the different factors paralyzing organization in the achievement of its ambitious mission in the region is conflict and deep rooted mistrust and antipathy among its member states. The region continues to experience high level violent conflict over the last few decades. The unfolding hostile relations between Ethiopia and Eritrea following the 'unnecessary' two years' war and the subsequent inability of IGAD to deter the war poisoned regional relations and exacerbate other conflicts (Healy, 2009) and war remains the key obstacle to any progress towards developing an improved regional security framework. The rapprochement of Ethiopia and Eritrea now primed the latter to be re-admitted into the regional organization IGAD (Al Jazeera, 2018) ${ }^{1}$. And the re-admission can potentially strengthen the sub regional organization to reorganize efforts in the fight against terrorist and extremists' groups that sprung in the region. Opportunities to promote good neighborliness, enhance peace and stability, and advance regional integration created based on the view expressed by African Union Commission Chairperson, Moussa Faki Mahamat (Ethiopian News Agency, 2018).

\section{CONCLUSION}

In its history, the year 2018 can be taken as a special milestone and momentum for the Horn of Africa and the wider Red Sea region. A new wind is blowing to transform politics and reconcile interstate divergences, which hundreds of thousands of young people have fled in search of safety and opportunities in Europe. Most importantly, the current Ethio-Eritrean diplomatic rapprochement to normalize relations and reconcile borders dissonances opens the possibility of redrawing regional economic and security dynamics which have become entrenched over the last two decades. Especially, the unfolded impasses following the deadliest two years EthioEritrean war of 1998-2000 was identified as a key driving scene for internal turmoil within both countries. The uninterrupted border skirmishes and exchange of gunfire, support of dissidents and rebel groups both in material and morally, subversion, hostages and stifling of individuals, militarization and ethos of militarism the two leadership in Addis Ababa and Asmara endavoured further endured hostilities and insecurity. To come out of these disturbing situations, the new prime minister of Ethiopia showed enthusiasm to end the disputes with Eritrea and bring lasting solutions to the decades of stalemate.

In the regard, the prevailing rapprochement and normalizations begun between the two nations can bring immense opportunities in the alleviation of the age-old security problems of the Horn of Africa. in short, the apparent peace deal and normalization of relations between the two foes, Ethiopia and Eritrea, can induces unanticipated outcomes to the security and development of the Horn of Africa: given the reconciliation of Djibouti-Eritrea and Eritrea-Somalia antipathy; opening of sub-regional economic cooperation and integrations in road, transport, tourism, trade and airlines; reduce proxies, destabilization, incursion, skirmishes, gunfire, militarization and violence. These entire development finals strengthen political certainty, harmony, trust, solidarity and interdependence in economic, political and socio-cultural terms.

\section{REFERENCES}

Abbink, J. (1998). Briefing: The Ethiopian and Eritrean Border Dispute. African Affairs, 97 (389), 551-556.

Abbink, J. (2003a). Ethiopia-Eritrea: Proxy Wars and Prospects of Peace in the Horn of Africa. Journal of Contemporary African Studies, 21 (3) 408-425.

Addis Standard. (2018, 18 September). 'Full Text of the Ethio-Eritrea Agreement in Jeddah. Retrieved from https://addisstandard.com/full-text-of-the-ethio-eritrea-agreement-signed-in-jeddah/.

African news. (2018,18 September). Eritrea, Djibouti leaders hold historic meeting in Saudi Arabia. Retrieved from http://www.africanews.com/2018/09/18/eritrea-djibouti-leaders-hold-historic-meeting-in-saudi-

\footnotetext{
${ }^{1}$ Eritrea suspended Eastern African body IGAD in 2007 contesting Ethiopia's unilateral military intervention in Somalia to fight antigovernment Islamist insurgents and militant groups, to which the former found it as illegally or morally unacceptable.
} 
arabia//.

African Review. (2018, 31 July). Somalia and Eritrea to restore diplomatic relations. Retrieved from http://www.africanreview.com/finance/economy/somalia-and-eritrea-to-restore-diplomatic-relations.

Al Jazeera. (2018). Ethiopia and Eritrea's second rapprochement. Retrievedhttps:/www.aljazeera.com/indepth/opinion/ethiopia-eritrea-rapprochement$180918135547856 . \mathrm{html}$.

Al Jazeera. (2018, 11 September). Eritrea consolidates Horn of Africa peace..Retrievedhttps://www.aljazeera.com/news/2018/09/eritrea-consolidates-horn-africa-peace-deal180910174538098.html.

Al Jazeera. (2018, 11 September).Ethiopia-Eritrea border opens for first time in 20 years. Retrieved fromhttps://www.aljazeera.com/news/2018/09/ethiopia-eritrea-border-opens-time-20-years180911082008249.html.

Al Jazeera. (2018, 30 July). Eritrea and Somalia agree to restore diplomatic relations.Retrievedhttps:/www.aljazeera.com/news/2018/07/eritrea-somalia-agree-restore-diplomaticrelations-180730152410668.html.

Alemseged Abbay. (2001). Not with them, not Without Them: The Staggering of Eritrea to Nationhood. Africa: Rivistatrimestrale di studi e documentazionedell'Istitutoitaliano per l'Africael'Oriente, 56 (4). 459-491.

Allafrican.com. (2018, 17 September). Ethiopia: Eritrea-Ethiopia Warming Ties Re-Open Trade Routes, Air Links..Retrieved from https://allafrica.com/stories/201809170433.html

Bahru Zewde. (2006). Eritrea and Ethiopia: In quest of a culture of peace and dialogue. in Leenco Lata (ed.), The Search for Peace: the Conflict between Ethiopia and Eritrea, proceedings of the scholarly conference on Ethiopia - Eritrea conflict, Oslo, Norway 6-7 July 2006.

BBC News. (2018, 18 September). Djibouti and Eritrea leaders meet after a decade. Retrieved from https://www.bbc.com/news/topics/cz4pr2gdgjyt/eritrea.

BBC News. (2018, 9 October). Ethiopian rebels based in Eritrea return home. Retrieved fromhttps://www.bbc.com/news/world/africa.

Bereketeab, R. (2010). The Complex Roots of the Second Eritrea- Ethiopia War: Re-examining the Causes. African Journal of International Affairs, 13 (1/2). 15-59.

Bereketeab, R. (2013). 'Introduction', in Redie B. (ed), The Horn of Africa: Intra-State and Inter-State Conflicts and Security, Pluto Press and Nordic Africa Institute.

Berhane Woldegabriel. (2006). Eritrea: A War for National Unity, in Leenco L. (ed.), The Search for Peace: the Conflict between Ethiopia and Eritrea, proceedings of the scholarly conference on Ethiopia - Eritrea conflict, Oslo, Norway 6-7 July 2006.

BeroukMesfin. (2000).The Eritrea-Djibouti border dispute. Situation Report. Institute for Security Studies.

BeroukMesfin.(2012). Ethiopia's Role and Foreign Policy in the Horn of Africa. International Journal of Ethiopian Studies, 6(1/2). 87-113

Daniel R. Mekonnen and Paulos Tesfagiorgis. (2011). The causes and consequences of the Eritrean-Ethiopian border conflict: The need for a holistic approach towards transitional justice, in Roba Sharamo and Berouk Mesfin (eds.), Regional Security in the post-Cold War Horn of Africa, Institute for Security Studies.

Dima, N. Sarbo .(2006). Ethiopia and Eritrea: Short-Sighted Solution, Long Term Problems. in Leenco Lata (ed.), The Search for Peace: the Conflict between Ethiopia and Eritrea, proceedings of the scholarly conference on Ethiopia - Eritrea conflict, Oslo, Norway 6-7 July 2006.

Ethiopian Broadcasting Corporations -EBC-. (2018, 31July). „C午

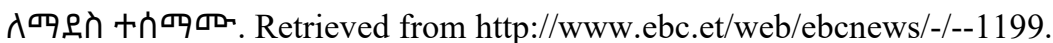

Ethiopian News Agency. (2018, 4 July). Normalizing Ethio-Eritrean Relations to Enhance Regional Integration: Scholars. Retrieved from https://www.ena.et/en/2018/07/04/normalizing-ethio-eritrean-relations-toenhance-regional-integration-scholars/.

Ethiopian News Agency. (2018, 8 September). AU Chairperson Hails Recent Positive Developments in Horn of Africa.. Retrieved from https:/www.ena.et/en/2018/09/08/au-chairperson-hails-recent-positivedevelopments-in-horn-of-africa/.

Ethiopian News Agency. (2018, 9 September). UN Chief Welcomes Djibouti Agreement between Eritrea, Ethiopia, Somalia. Retrieved from https://www.ena.et/en/2018/09/09/un-chief-welcomes-djiboutiagreement-between-eritrea-ethiopia-somalia/.

Gebru Asrat .(2006). Towards a Sustainable Peace between Ethiopia and Eritrea in Leenco Lata (ed.), The Search for Peace: the Conflict between Ethiopia and Eritrea, proceedings of the scholarly conference on Ethiopia - Eritrea conflict, Oslo, Norway 6-7 July 2006.

Healy, S. (2007). Eritrea's Economic Survival: Summary record of a conference held on 20 April 2007. London: the Royal Institute of International Affairs.

Healy, S. (2009).Peacemaking In The Midst Of War: An Assessment of IGAD's Contribution to Regional 
Security. Regional and Global Axes of Conflict -Working Paper.. 59- London: the Royal Institute of International Affairs.

Healy, S. and Plaut, M. (2007). Ethiopia and Eritrea: Allergic to Persuasion. Briefing paper, London: the Royal Institute of International Affairs.

ICG. (2008). Beyond The Fragile Peace Between Ethiopia And Eritrea: Averting New War, Africa Report No.141. Retrieved fromhttps://www.files.ethz.ch/isn/57502/141_ethiopia_and_eritrea.pdf

International Crisis Group-ICG (2005). Ethiopia and Eritrea: Preventing War, Africa Report. No. 101. Retrieved from https://www.refworld.org/pdfid/43bd4a222.pdf

International Crisis Group-ICG (2010). Eritrea: The Siege State, Africa Report, No.163.

International Crisis Group-ICG. (2003). Ethiopia and Eritrea: War or Peace? Africa Report No. Retrieved from 68. https://www.files.ethz.ch/isn/28748/068_ethiopia_and_eritrea._war_or_peace.pdf

Iyob, R. (2000). "The Ethiopian-Eritrean Conflict: Diasporic vs. Hegemonic States in the Horn of Africa, 19912000", Journal of Modern African Studies 38. 4. 659-682.

Kassahun Berhanu. (2013). Conflicts in the Horn of Africa and Implications for Regional Security, in Redie Bereketeab (ed), The Horn of Africa: Intra-State and Inter-StateConflicts and Security. Pluto Press and Nordic Africa Institute.

Kidane Mengisteab. (2011). Critical Factors in the Horn of Africa's Raging Conflicts. Discussion Paper. Uppsala: Nordiska Afrika institutet.

Kidane Mengisteab. (2013).Poverty, Inequality, State Identity and Chronic Inter-State Conflicts in the Horn of Africa, in Redie Bereketeab (ed), The Horn of Africa: Intra-State and Inter-State Conflicts and Security. Pluto Press and Nordic Africa Institute.

Kidanu Atinafu and Endalcachew Bayeh. (2015). The Ethio-Eritrean Post-War Stalemate: An Assessment on the Causes and Prospects. Humanities and Social Sciences. 3. (2), 96-101.

Kidist Mulugeta. (2011). The Ethiopian-Eritrean War of 1998-2000: An Analysis of its Causes, Course, Impacts and Prospects, in Roba Sharamo and Berouk Mesfin (eds.), Regional Security in the post-Cold War Horn of Africa, Institute for Security Studies.

Leenco Lata. (2006). Introduction, in Leenco Lata (ed.), The Search for Peace: the Conflict between Ethiopia and Eritrea, proceedings of the scholarly conference on Ethiopia - Eritrea conflict, Oslo, Norway 6-7 July 2006.

Life and Peace Institute. (2018, 3 October). Imagining Peace: Ethiopia-Eritrea Rapprochement. Demessie Fantaye (ed). Retrieved from https://life-peace.org/resource/imagining-peace-ethiopia-eritrearapprochement/.

Lyons, T. (2009). The Ethiopia-Eritrea Conflict and the Search for Peace in the Horn of Africa."Review of African Political Economy 36 (120), 167- 180

Mahmood, O. and Meressa K (2018), 'Can improved Ethiopia-Eritrea relations stabilise the region?'Report from Institute for Security Studies. https://reliefweb.int/report/eritrea/can-improved-ethiopia-eritrea-relationsstabilise-region

Medhane Tadesse. (1999).The Eritrean-Ethiopian War: Retrospect and Prospect; Addis Ababa: Mega printing press.

Mosley, J. (2014), Eritrea and Ethiopia: Beyond the Impasse, Briefing, Africa Programme| FP BP 2014/01.

Plaut, M. (2005/2006). "Ethiopia and Eritrea: Returning to War?.'International Journal of Ethiopian Studies, 2 $(1 / 2), 179-194$.

Plaut, M.(2018, 29 July 29). Ethiopia Orders 'Eritrean Opposition' Parties Cease Anti-Eritrean Activities. Tesfanews, Retrieved from https:/www.tesfanews.net/ethiopia-order-eritrea-opposition-cease-anti-eritreaactivities/

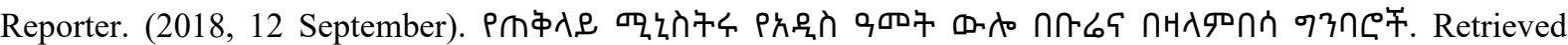
from https://www.ethiopianreporter.com/article/12997.

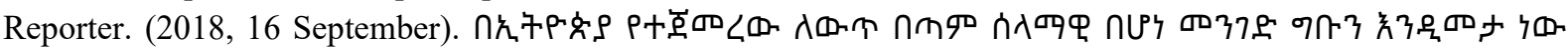

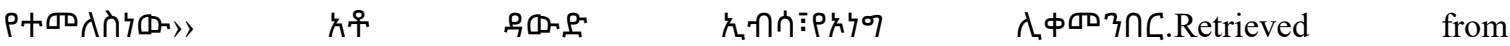
https://www.ethiopianreporter.com/article/13018.

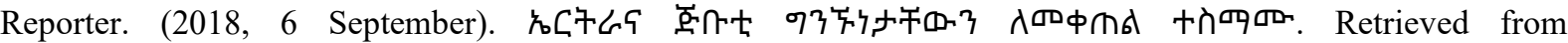
https://www.ethiopianreporter.com/article/12938.

Reuters. (2018, 13 July.). Eritrea's president to visit Ethiopia, embassy to re-open. Retrieved from https://www.reuters.com/article/us-ethiopia-eritrea/eritreas-president-to-visit-ethiopia-embassy-to-re-openidUSKBN1K30NE.

Reuters. (2018, 30 July). Somalia, Eritrea to establish diplomatic ties, open embassies. Retrieved from https://www.reuters.com/article/us-eritrea-somalia-diplomacy/somalia-eritrea-to-.establish-diplomatic-tiesopen-embassies-idUSKBN1KK1O5. 
Reuters. (2018, 9 July). Ex-foes Ethiopia, Eritrea eye peace dividend after historic deal. Retrieved from https://www.reuters.com/article/us-ethiopia-eritrea-economy/ex-foes-ethiopia-eritrea-eye-peace-dividendafter-historic-deal-idUSKBN1JZ2KS.

Sudan Tribune. (2016, 16 May). Ethiopia says foiled Eritrea-backed terror attack. Retrieved from http://www.sudantribune.com/spip.php?article58943.

Tekeste Negash and Tronvoll, K. (2000).Brothers at War: Making Sense of the Eritrea - Ethiopian War. Oxford: James Currey.

Tewodros Makonnen and Halellujah Lulie. (2014). Ethiopia, Regional Integration and the COMESA Free Trade Area. Occasional Paper 198. South African Institute of International Affairs.

The Guardian. (2012, 18 January).Five European tourists killed in attack in Ethiopia. Retrieved from https://www.theguardian.com/world/2012/jan/18/european-tourists-killed-ethiopia.

Trivelli,. R. (1998). Divided Histories, Opportunistic Alliances: Background Notes on the Ethiopian-Eritrean War. Africa Spectrum. 33(3), 257-289.

Urgessa Deressa. (2014). The Ethio-Djibouti Relations: Implications for Sub-regional Integration Schemes In the Horn of Africa. Unpublished MA Thesis, Addis Ababa University.

VoA. (2018, 4 August). Unresolved Eritrea-Djibouti Tensions Threaten Regional Peace. Retrieved from https://www.voanews.com/a/unresolved-eritrea-djibouti-tensions-threaten-strides-toward-regionalpeace/4513779.html.

Wuhibegezer Ferede. (2014|). Fundamental Consequences of the Ethio- Eritrean War [1998-2000]. Journal of Conflictology, 5 (2), 30-47. 